evaluation of undergraduate teaching via HEEC in late 2009 . Some initiatives on teaching evaluation will be explored in the new cycle.

\section{Academic Freedom and Public Intellectuals in China}

\section{QIANG ZHA}

Qiang Zha is assistant professor in the Faculty of Education, York University, Toronto, Canada. E-mail: qzha@edu.yorku.ca.

A cademic freedom has always been viewed as problematic in China. The recent academic integrity crisis on university campuses and governmental intervention have once again brought this issue to the fore. Since 2002, China's Ministry of Education has promulgated a series of policies aiming to clean up academic corruption on university campuses. Most recently, in March 2009, it announced severe penalties for academic misbehavior. Then, what is the status quo of academic freedom in Chinese universities? To consider this issue, it is necessary to go back to the Confucian intellectual tradition, as it viewed the relations between academics and the state in a quite different way from the Western notion. This article starts by offering a historical perspective on academic freedom in China, followed by an effort at discerning the trajectory of its evolution over the last century, as a way of exploring the causes of corruption among contemporary Chinese university scholars.

\section{UNITY OF KNOWLEDGE AND ACTION}

Unlike the Western tradition, where scholars believe in the power of words and seek to be public intellectuals through engaging in critical debate, the Confucian tradition prompted Chinese scholars to realize their ideals through action and a kind of direct responsibility for managing the state. This tradition was best explained by the Confucian canons of knowledge and the imperial examination system that selected intellectuals to serve as scholar-officials. Knowledge was less a matter of understanding the world than of changing it, and scholars were expected to "cultivate the self, manage the family, govern the country, and bring peace to the world." Put explicitly, they sought a unity of knowledge and action through their roles as scholar-officials. Rather than considering themselves as independent social critics, they saw themselves as offsetting political authority with intellectual authority and being responsible to "tame" the ruler so that he would be a "Philosopher King." While there were inevitably cases of cynicism and corruption, this scholar-official role did not necessarily confine Confucian scholars in terms of independent thinking. More often, they were seen as upholding social justice and morality with their "iron shoulders."

\section{A Century of Ups and Downs}

The abolition of the imperial examination system in 1905 led to the formation of an independent intellectual class. In the May 4th Movement of I9I9, often called China's enlightenment, the Confucian tradition was repudiated and both radicalism and utilitarianism began to characterize Chinese academia. The former resulted in revolutionary activism, while the latter led to a growing cynicism among Chinese scholars. Since then Chinese scholarship seems to have oscillated between these opposite extremes. The May 4th Movement witnessed the emergence of radical intellectuals, many of whom later joined the Chinese Communist Party and contributed to the formation of the People's Republic of China in I949. Eight years later, in I957, when Khrushchev denounced Stalin at the 2oth Congress of the Soviet Communist Party, Chinese intellectuals participated enthusiastically in the Hundred Flowers Campaign, suggesting that China's new government should "govern democratically" and accept criticism. Mao Zedong viewed this as violating a healthy level of criticism and launched the Anti-Rightist Movement. Many university-based intellectuals were labelled "rightists" and sent into exile.

The Anti-Rightist Movement resulted in Chinese intellectuals feeling themselves to be objects of suspicion and oppression. They became largely voiceless from the late I950s to the

The abolition of the imperial examination system in 1905 led to the formation of an independent intellectual class.

late I970s, and some became cynical. This may have contributed to such disasters as the great famine of the early I960s and the Cultural Revolution between I966 and I976. When Deng Xiaoping launched a series of economic reforms that led to the gradual implementation of a market economy, the Chinese government found itself groping to resolve the contradictions that arose from its new and controversial policy. Intellectuals were again encouraged to contribute actively to reform, in the name of "respecting knowledge and talent." Irritated by China's economic backwardness and the ultraleft thinking of the Cultural Revolution, many Chinese intellectuals shared a strong commitment to the pursuit of freedom and democracy in the I980s. Thus, the I980s witnessed a second enlightenment era with a predominant belief among university faculty that the reforms had not gone far enough. Having seen the political liberalization undertaken in the name of glasnost by Gorbachev, they were hoping for comparable reform in China. This culminated in the June $4^{\text {th Incident in } 1989 .}$

Leaving the idealist and passionate ig8os behind, Chinese intellectuals experienced a transformation close to what their Western counterparts did after I968: a split between intellectual reformer and academic worker. A very few continued as liberal intellectuals, but the majority retreated to university cam- 
puses to seek knowledge and academic pursuits for their own sake. Chinese intellectuals now do contribute to policy formation at various levels, through offering professional advice, but they rarely take up the role of social critics or social activists. They have adopted a stance that is termed "constructive criticism" and does not necessarily reflect the radical social commitment of liberal intellectuals. As the Western idea of academic freedom and direct criticism of government has gradually lost its attractiveness, in the face of China's economic success more and more scholars in Chinese universities favor "constructive criticism."

\section{Chinese Scholars and Academic Corruption}

After 1992 China changed very rapidly, making some scholars anxious. Along with increasing wealth, the market economy has also encouraged utilitarianism and a one-sided emphasis on accumulating material wealth. Scholars have found their elite culture replaced by a secular one. Some of them have been attracted by various "shortcuts" to power and influence, especially when their academic integrity has lost its ideological underpinnings and utilitarianism has taken over. It is in this context that plagiarism has become widespread, even in top universities. A recent article in Science (March I6, 2009) on plagiarizing or fabricating data by researchers at Zhejing University (one of China's top universities) put a spotlight on the crisis of academic integrity in Chinese universities and the fact that it is now attracting international attention. This shows a widely held perception that corruption is not limited to the power sphere in China but has penetrated academia. In October 2009, when the Chinese government celebrated the Goth anniversary of the founding of the People's Republic of China and announced Chinese universities now ranked the world's fifth in terms of research capacity, based on the volume of the research papers published, criticism came up immediately from within and outside of the sector, citing the increasing plagiarism and declining integrity.

The Anti-Rightist Movement resulted in Chinese intellectuals feeling themselves to be objects of suspicion and oppression. They became largely voiceless from the late 1950 s to the late 1970 s

Realizing that academic corruption could jeopardize China's ambition of creating world-class universities, the government has stepped in. While the government used to be viewed as an obstacle to academic freedom, it has now had to become a watchdog for the academic integrity of scholars and universities in China. Elsewhere, this is a time that cries out for intellectuals to exercise self-mastery and self-discipline. China is not exempt from these trends, but Chinese scholars may be even more vulnerable, due to the character of the political regime and discontinuity with the Confucian scholarly tra- dition. Until Chinese scholars can show themselves to be accountable and exercise a kind of reciprocal responsibility, they may not be entitled to the kinds of autonomy and academic freedom that have been part of the Western tradition. While the Confucian classics are now being reintroduced into the curriculum, it is not clear whether this will lead to a renaissance of China's tradition of intellectual authority and a high degree of social responsibility.

\section{Institutional Diversification in Chinese Higher Education}

\section{Hubert ERTl and Kai Yu}

Hubert Ertl is lecturer in higher education at the Department of Education at the University of Oxford and fellow of Linacre College, Oxford. E-mail: hubert.ertl@education.ox.ac.uk. Kai Yu completed his doctorate on diversification in higher education at the Department of Education, University of Oxford and now works at the Graduate School of Education, Shanghai Jiao Tong University, China. E-mail: kai286@gmail.com.

China's higher education system has experienced unprecedented growth since 1998. According to the most recent data from the Ministry of Education in China, the number of new students entering undergraduate programs rose from around I million in 1998 to some 6 million in 2008. This increase resulted in a total number of students of over 20 million in 2008, making China the world's largest provider of higher education.

With the rapid expansion in student numbers came the introduction of several new types of degree-granting institutions. As outlined in an article by Ruth Hayhoe and Jing Lin in IHE (Spring 2008), private colleges and duli xueyuan or independent colleges, which are set up by public universities with the contribution of a private investor, account for a substantial share of increased enrollments: within just six years $(2000$ to 2006) 3I8 independent colleges were established. Now one in six students studying for an undergraduate degree in China is attending an independent or a private college.

This article reports on an exploratory study comparing an independent college and a private college with two public institutions located in a provincial capital in southeastern China. The two public institutions (one university and one college, according to the official classification of higher education institutions) are well established and-in line with government regulation-charge the same level of tuition fees. The independent and the private colleges are younger institutions and charge around 2.5 times higher fees than the public institutions. 